\title{
IDENTIFIKASI TANAMAN JOMBANG (Taraxacum officinale) YANG TUMBUH DI BATU MALANG
}

\author{
Elok Widayanti ${ }^{1)}$ dan Nita Supriyati ${ }^{2)}$ \\ ${ }^{1)}$ Politeknik Kesehatan Kemenkes Malang \\ ${ }^{2)}$ Balai Besar Litbang Tanaman Obat dan Obat Tradisional Tawangmangu \\ e-mail : elok.widayanti@gmail.com; nita_supriyati@yahoo.com
}

\begin{abstract}
ABSTRAK
Tanaman jombang (Taraxacum officinale) merupakan salah satu tanaman obat yang dapat digunakan sebagai obat tradisional untuk gula darah (hiperglikemia), peluruh kencing, hepatoprotektor, tukak lambung dan lain-lain. Pada penelitian ini telah dilakukan karakterisasi terhadap tanaman jombang yang tumbuh di daerah Batu Malang. Tujuan dari karakterisasi ini adalah untuk mengetahui parameter non spesifik dari ekstrak etanol dan kandungan metabolit sekunder. Ekstrak diperoleh dengan metode maserasi menggunakan pelarut etanol $70 \%$ didapatkan rendemen sebesar 13,03\% berupa ekstrak berkonsistensi kental, berwarna coklat tua dan berbau khas. Kadar air 8,79\% dan kadar abu 11,195\%. Kadar sari larut air 28,77\% dan kadar sari larut etanol 18,226\%. Kandungan golongan kimia ekstrak etanol jombang adalah alkaloid, flavonoid, saponin, tanin dan polifenol.
\end{abstract}

Kata kunci : Taraxacum officinale, jombang, karakterisasi, skrining fitokimia

\section{IDENTIFICATION OF JOMBANG (Taraxacum officinale) THAT GROW IN BATU MALANG}

\begin{abstract}
Jombang (Taraxacum officinale) is one of the medicinal plants that can be used as traditional medicine for blood sugar (hyperglycemia), urinary laxative, hepatoprotector, gastric ulcer and others. In this study, identification of jombang that have grown in the Batu Malang area has been carried out. The purpose of this characterization is to find out the non-specific parameters of ethanol extract and the content of secondary metabolites. The extract was obtained by maceration method using $70 \%$ ethanol solvent. The yield of $13.03 \%$ was obtained in the form of an extract which was consistently thick, dark brown and distinctive smell. Water content of $8.79 \%$ and ash content of $11.195 \%$. Water soluble extract content of $28.77 \%$ and soluble ethanol extract content of $18.226 \%$. The chemical content of jombang ethanol extract is alkaloids, flavonoids, saponins, tannins and polyphenols.
\end{abstract}

Keywords: Taraxacum officinale, jombang, characterization, phytochemical screening

\section{PENDAHULUAN}

Indonesia terkenal dengan khasanah tanaman obatnya. Namun demikian, penelitian sekaligus pengembangan tanaman obat Indonesia dirasakan belum maksimal. Sementara, di negara lain kini sedang gencargencarnya menggunakan pengobatan tradisional dengan mencari upaya pengobatan melalui bahan-bahan yang tersedia di alam. Saat ini Indonesia mulai membuka mata atas potensi yang terkandung di dalamnya. Salah satu upayanya dengan memperkenalkan tanaman obat sebagai obat tradisional, selain menggunakan bahan ramuan dari tanaman tertentu yang mudah didapat disekitar lingkungan, juga resiko yang ditimbulkan kecil. Tanaman-tanaman yang berkhasiat sebagai obat telah dipelajari secara ilmiah dan hasilnya mendukung bahwa tanaman obat memiliki kandungan zat-zat atau senyawa yang secara klinis terbukti bermanfaat bagi kesehatan (Djamil, et all., 2014).

Tanaman jombang (Taraxacum officinale) merupakan tanaman asli Eropa dan 
menyebar ke daerah iklim sedang di wilayah Asia Selatan hingga Himalaya. Tanaman ini diintroduksi dan ditanam di Semenanjung Malaysia, Indonesia (Jawa Barat) dan Filiphina dibudidayakan sebagai sayuran dan obat-obatan. Saat ini jombang telah menyebar hampir di seluruh dunia. Tanaman jombang dapat digunakan sebagai obat anti radang, penurun kadar gula darah, hepatoprotektor, anti oksidan dan juga diuretic (Mooryati,1997 dan Akashi, et all., 1994).

Pada penelitian Tita, et all., (1993) (menggunakan ekstrak etanol $95 \%$ herba jombang dengan dosis $100 \mathrm{mg} / \mathrm{kg}$ bb yang diberikan secara intraperitoneal pada mencit dapat menghambat pembengkakan telapak kaki mencit yang diinduksi karagenan hingga 42\%. Selain itu menurut Racz-Kotilla (1974) pemberian ekstrak etanol 95\% herba jombang dengan dosis $8-50 \mathrm{~mL} / \mathrm{kg}$ bb pada tikus per oral mempunyai efek diuretik dan penurunan berat badan. Pada pemberian ekstrak etanol $50 \%$ herba jombang pada tikus dengan dosis $250 \mathrm{mg} / \mathrm{kg}$ bb atau $1 \mathrm{~g} / \mathrm{kg}$ bb pada kelinci dapat menurunkan kadar gula darah (Dhar, et all., 1968). Sedangkan pemberian ekstrak air akar jombang dosis $25 \mathrm{mg} / \mathrm{kg}$ bb dapat menurunkan kadar gula darah mencit yang dibuat hiperglikemia (Neef, et all., 1995).

Efek farmakologi suatu tanaman obat tergantung dari kualitas ekstrak tanaman obat senyawa kimia atau zat aktif yang terkandung didalam tanaman obat tersebut. Sedangkan kandungan senyawa kimia selain dipengaruhi secara genetis juga dapat dipengaruhi oleh kondisi lingkungan (suhu udara, $\mathrm{pH}$ tanah, jenis tanah, ketinggian tempat tumbuh, lokasi tumbuh, tanaman yang tumbuh di sekitarnya, letak astronomis, kelembaban dan curah hujan) serta umur tanaman. Pada penelitian ini akan dilakukan karakterisasi herba Jombang yang dibudidayakan di Balai Materia Medika Batu Malang.

\section{BAHAN DAN METODE}

1. Bahan

Bahan yang digunakan daun segar jombang yang telah diperlakukan sebagai berikut :

Benih berasal dari koleksi Balai Materia Medika Batu. Sebelum penanaman dilakukan penyemaian benih dengan waktu \pm 1 bulan sampai bibit siap dipindah ke lahan. Selama masa tanam dilakukan pemeliharaan meliputi kegiatan pengairan, penyiangan, pemupukan, dan pengendalian hama penyakit. Tanaman siap dipanen pada umur 3 bulan di lahan atau setelah tanaman masuk ke fase pembungaan.

2. Pembuatan simplisia dan serbuk

Daun jombang dicuci kemudian ditiriskan dan dipanaskan dibawah sinar matahari. Simplisia jombang kemudian diserbuk menggunakan grinder.

3. Pembuatan ekstrak etanol

Serbuk diekstraksi dengan teknik maserasi selama 3 x 24 jam menggunakan pelarut etanol $70 \%$

4. Karakterisasi parameter non spesifik ekstrak

- Penetapan kadar air

- Penetapan kadar abu

5. Karakterisasi parameter spesifik ekstrak

- Pemeriksaan organoleptis

- Penetapan kadar sari larut air

- Penetapan kadar sari larut etanol

6. Skrining Fitokimia

Mengacu prosedur Acta Manila (1978)

\section{HASIL DAN PEMBAHASAN}

Pada penelitian ini bertujuan untuk mengetahui parameter non spesifik dari ekstrak etanol dan kandungan metabolit sekundernya. Penelitian ini dilakukan di Laboratorium Balai Besar Litbang Tanaman Obat dan Obat Tradisional Tawangmangu menggunakan bahan tanaman jombang yang dibudidayakan di Balai Materia Medika Batu yang berada di ketinggian $\pm 680-1200$ mdpl dengan jenis tanah andosol. Tanaman jombang dapat tumbuh baik di dataran menengah 800-1200 mdpl (Kementerian Kesehatan RI, 2011). Penanaman jombang dilakukan di lahan yang tidak ternaungi sehingga terkena langsung sinar matahari. Menurut penelitian tentang kandungan flavonoid pada daun sambung nyawa berbeda antara tanaman yang dinaungi dengan tanaman yang tidak dinaungi. Kandungan flavonoid tertinggi diperoleh jika tanaman sambung nyawa dinaungi $55 \%$, sedangkan kandungan flavonoid tanaman dengan naungan $75 \%$ terendah (Dainy, 2006). Selain itu juga beberapa tanaman obat yang tumbuh baik pada lahan dengan naungan antara lain keji beling, kapulogo dan kumis kucing (Kementerian Kesehatan RI, 2011). Tetapi 
untuk tanaman jombang sendiri masih belum ada penelitiannya sehingga masih belum bisa dipastikan apakah jombang akan tumbuh lebih baik di bawah naungan.

Lokasi tumbuhan sendiri berarti lingkungan (tanah dan atmosfer) tempat tumbuhan berinteraksi dengan lingkungan yang berupa energi (cuaca, suhu, cahaya) dan materi (air, senyawa organik dan senyawa anorganik). Variasi lingkungan inilah yang dianggap berpengaruh terhadap kualitas ekstrak tumbuhan obat (Hernani dan Nurdjanah, 2009).

Jombang yang telah dipanen disortasi, dicuci, dilayukan dan dikeringkan dibawah sinar matahari untuk mendapatkan simplisia. Menurut penelitian lama proses pelayuan dan pengeringan terhadap daun tempuyung berpengaruh terhadap kadar flavonoidnya. Untuk daun tempuyung yang dikeringkan dengan oven, produk berwarna lebih hijau dibandingkan dengan penjemuran matahari karena suhu oven bersifat lebih stabil dibandingkan dengan suhu sinar matahari yang sangat bervariasi $\left(35-47^{\circ} \mathrm{C}\right)$. Kadar flavonoid yang tertinggi dihasilkan dari lama pelayuan 1 hari dengan pengeringan oven suhu $40^{\circ} \mathrm{C}$ (Hernani, et all., 1997).

Jombang yang telah dikeringkan
menjadi simplisia dilakukan proses penyerbukan dan ekstraksi. Metode ekstraksi yang digunakan adalah maserasi dengan pelarut etanol $70 \%$ selama 3 x 24 jam. Hasilnya dipekatkan dengan meletakkan di atas waterbath sampai didapatkan ekstrak kental dengan berat konstan. Dari hasil maserasi ini didapatkan rendemen sebesar $13,03 \%$.

Tabel 1. Hasil pemeriksaan parameter non spesifik ekstrak herba jombang

\begin{tabular}{|c|c|c|c|}
\hline No & Parameter & Hasil & Standar* \\
\hline 1 & Kadar air & $8,79 \%$ & $<11 \%$ \\
\hline 2 & Kadar abu & $11,2 \%$ & $<17 \%$ \\
\hline
\end{tabular}

Kadar air adalah banyaknya air yang diserap dengan tujuan memberikan batasan minimal atau rentang tentang besarnya kandungan air dalam bahan (WHO, 2007). Hasil pemeriksaan didapatkan kadar air sebesar 8,79\%. Hasil ini sudah memenuhi kadar yang dipersyaratkan oleh WHO yaitu kadar air tidak boleh lebih dari $11 \%$ (Harborne, 1996).

Parameter kadar abu memberikan gambaran kandungan mineral yang berasal dari proses awal sampai terbentuknya ekstrak. Bahan dipanaskan pada suhu di mana senyawa organik dan turunannya tereduksi dan menguap, sehingga tinggal unsur mineral atau anoganik. Hasilnya adalah 11,2\% dimana kadar abu yang dipersyaratkan oleh WHO (2007) tidak lebih dari $17 \%$ (Harborne, 1996).

Tabel 2. Hasil pemeriksaan parameter spesifik ekstrak herba jombang

\begin{tabular}{|c|c|c|c|}
\hline No & Parameter & Hasil & Standar* \\
\hline \multirow[t]{6}{*}{1} & Organoleptis & & \multirow{5}{*}{$\begin{array}{c}\text { Berbau } \\
\text { Sedikit } \\
\text { pahit } \\
\text { /sepat }\end{array}$} \\
\hline & warna & $\begin{array}{l}\text { coklat } \\
\text { tua }\end{array}$ & \\
\hline & bau khas & berbau & \\
\hline & rasa & sepat & \\
\hline & bentuk & kental & \\
\hline & $\begin{array}{l}\text { Kadar sari larut } \\
\text { air }\end{array}$ & $28,77 \%$ & \multirow[t]{7}{*}{$>30 \%$} \\
\hline 3 & $\begin{array}{l}\text { Kadar sari larut } \\
\text { etanol }\end{array}$ & $18,23 \%$ & \\
\hline 4 & $\begin{array}{l}\text { Kandungan } \\
\text { golongan kimia }\end{array}$ & & \\
\hline & alkaloid & + & \\
\hline & flavonoid & + & \\
\hline & saponin & + & \\
\hline & tanin\&polifenol & + & \\
\hline
\end{tabular}

*Mengacu pada WHO (2007)

Penentuan organoleptik ini termasuk salah satu parameter spesifik yang ditentukan menggunakan panca indera dan bertujuan untuk pengenalan awal secara sederhana dan subyektif. Warna ekstraknya coklat, berbau khas, rasa sepat dan bentuknya kental.

Pengujian kadar sari dimaksudkan agar dapat memberikan gambaran awal sejumlah kandungan dengan cara melarutkan ekstrak dalam pelarut organik (etanol atau air). Selanjutnya adalah uji kadar sari larut air yang didapatkan sebesar 28,77\% dan kadar sari larut etanol sebesar 18,23\%. Kadar sari larut air mempunyai nilai yang lebih tinggi dibandingkan dengan kadar sari larut etanol. Hal ini dimungkinkan kandungan senyawa polar lebih banyak dibandingkan dengan senyawa yang non polar. Sesuai dengan 
prinsip like dissolves like yakni adanya kecenderungan kuat bagi senyawa polar larut dalam pelarut polar, dan sebaliknya. Menurut literatur bahwa kadar sari larut air tidak boleh kurang dari $30 \%$, hal ini menunjukkan kadar yang masih berada dibawah standar (Harborne, 1996).

Pada penentuan kandungan golongan kimia ekstrak diketahui bahwa ekstrak jombang mengandung alkaloid, flavonoid, tannin dan saponin. Menurut penelitian bahwa jombang dengan berbagai variasi pelarut mengandung alkaloid, flavonoid, steroid, saponin, tanin dan triterpenoid (Amin, et all., 2013).

Sampel mengandung alkaloid, hal ini ditunjukkan dengan terbentuknya endapan pada uji menggunakan pereaksi Meyer, Wagner dan Dragendorff. Alkaloid mencakup senyawa bersifat basa yang mengandung satu atau lebih atom nitrogen, biasanya dalam gabungan sebagai bagian dari system siklik. Alkaloid seringkali beracun bagi manusia dan banyak mempunyai kegiatan fisiologis yang menonjol, jadi digunakan secara luas dalam bidang pengobatan (Rusdi, 1990).

Kandungan saponin dalam ekstrak dapat ditandai dengan pembentukan busa yang tidak hilang selama 30 detik saat uji Forth. Timbulnya busa menunjukkan adanya glikosida yang mempunyai kemampuan membentuk buih dalam air yang terhidrolisis menjadi glukosa dan senyawa lainnya (Octavia, 2009).

Kandungan Flavonoid dapat ditunjukkan adanya warna merah atau jingga menunjukkan adanya flavonol, flavanon dan atau xanton (WHO, 2007). Uji Wilstater cyanidin biasa digunakan untuk mendeteksi senyawa yang mempunyai inti $\alpha$ benzopyron. Warna orange yang terbentuk pada uji Bate Smith-Mertcalf dan warna merah pada uji Wilstater disebabkan karena terbentuknya garam flavylium (Achmad, 1986).

Kandungan Tanin ditunjukkan dengan terbentuknya endapan. Adanya tannin akan mengendapkan protein gelatin. Tanin bereaksi dengan gelatin membentuk kopolimer mantap yang tidak larut dalam air (Amin, 2013).

\section{KESIMPULAN}

Tanaman Jombang yang dibudidayakan Balai Materia Medika Batu mempunyai ekstrak etanol yang positif mengandung alkaloid, flavonoid, tannin dan saponin dengan kadar air 8,79\%, kadar abu $11,195 \%$, adar sari larut air $28,77 \%$ dan kadar sari larut etanol 18,226\%.

\section{UCAPAN TERIMAKASIH}

Penulis mengucapkan terimakasih kepada Balai Besar Penelitian dan Pengembangan Tanaman Obat dan Obat Tradisional atas dukungan dananya.

\section{DAFTAR PUSTAKA}

Achmad, S.A. 1986. Kimia Organik Bahan Alam. Jakarta : Karnunika.

Akashi, T., T. Furuno, T. Takahashi, and S. Ayabe. 1994. Biosynthesis of triterpenoid in cultured cell, and regenered and wild plants organ of Taraxacum officinale. Phytochemistry 36(2):303-308.

Amin M, S.S. Sawhney, and M.M.S. Jassal., 2013. Qualitative and quantitative analysis of phytochemicalsof Taraxacum officinale. Wudpecker Journal of Pharmacy and Pharmocology 2(1):1-5.

Dainy N.C. 2006. Produksi dan Kandungan Flavonoid Daun Sambung Nyawa (Gynura procumbens. Lourr. Merr) pada Berbagai Tingkat Naungan dan Umur pemangkasan. IPB Bogor.

Dhar, M. L., M. M. Dhar, B. N. Dhawan.B. N. Mehotraand and C. Ray. 1968. Screening Indian plants for biological activity. Part I. Indian. Journal of Experimental Biology. 6: 232-240.

Djamil. R., W. Winarti, dan I. Yuniasari. 2014. Identifikasi Senyawa Flavonoid Dari Ekstrak Methanol Herba Jombang (Taraxacum officinale (asteraceae)) Secara Spektrofotometri Ultravioletvis. Fakultas Farmasi universitas Pancasila, Jakarta. 
Harborne, J. 1996. Metode Fitokimia: Penuntun Cara Modern Menganalisis Tumbuhan. Cetakan kedua. Penerjemah: Padmawinata, K. dan I. Soediro. Bandung: Penerbit ITB.

Hernani dan R. Nurdjanah. 2009. Aspek Pengeringan Dalam Mempertahankan Kandungan Metabolit Sekunder Pada Tanaman Obat. Perkembangan Teknologi. Balai Besar Penelitian dan Pengembangan Pascapanen Pertanian. Hal 33-39.

Hernani, Sudiarto, M. Rahardjo dan H. Muhammad. 1997. Aspek stadia pertumbuhan dan pascapanen terhadap mutu tempuyung. Warta Perhimpunan Peneliti Bahan Obat Alami (Perhipba) 5 (IV) : 14-17.

Kementerian Kesehatan RI. 2011. Pedoman Umum Budidaya Tanaman Obat.

Mooryati, S. 1997. Alam Sumber Kesehatan, Manfaat dan Kegunaan. Balai Pustaka. Indonesia.

Neef. H., P. DeClercq and G. Laekeman. 1995. Hypoglycemic activity of selected European plants. Phytotherapy Research. 9: 45-48.
Octavia D.R. 2009. Uji Aktivitas Radikal Ekstrak Petroleum Eter, Etil Asetat dan Etanol Daun Binahong (Anredera corfolia (Tenore) Steen) dengan Metode DPPH (2,2-difenil-1pikrihidrasil). Fakultas Farmasi Universitas Muhamadiyah. Surakarta.

Racz-Kotilla E, G Racz, and A Solomon. 1974. The action of Taraxacum offi cinale extracts on the body weight and diuresis of laboratory animals. Planta Medica. 26: 212-217.

Rusdi. 1990. Tetumbuhan sebagai sumber bahan obat. Puslit Universitas Andalas. Padang.

Tita, B., U. Bello, P. Faccendini, and R. Bartolini. 1993. Taraxacumofficinale W: Pharmacological effect of ethanol extract. Pharmacol Res 27(Suppl 1):2324.

WHO. 2007. Monograph on selected medicinal plant. volume 3 . hal 328337. 